\title{
Transgenic Elite Lines of Carioca Seeded Common Bean (Phaseolus Vulgaris L.) With Multiple Resistance to Viruses Reduce Cowpea Mild Mottle Virus Transmission
}

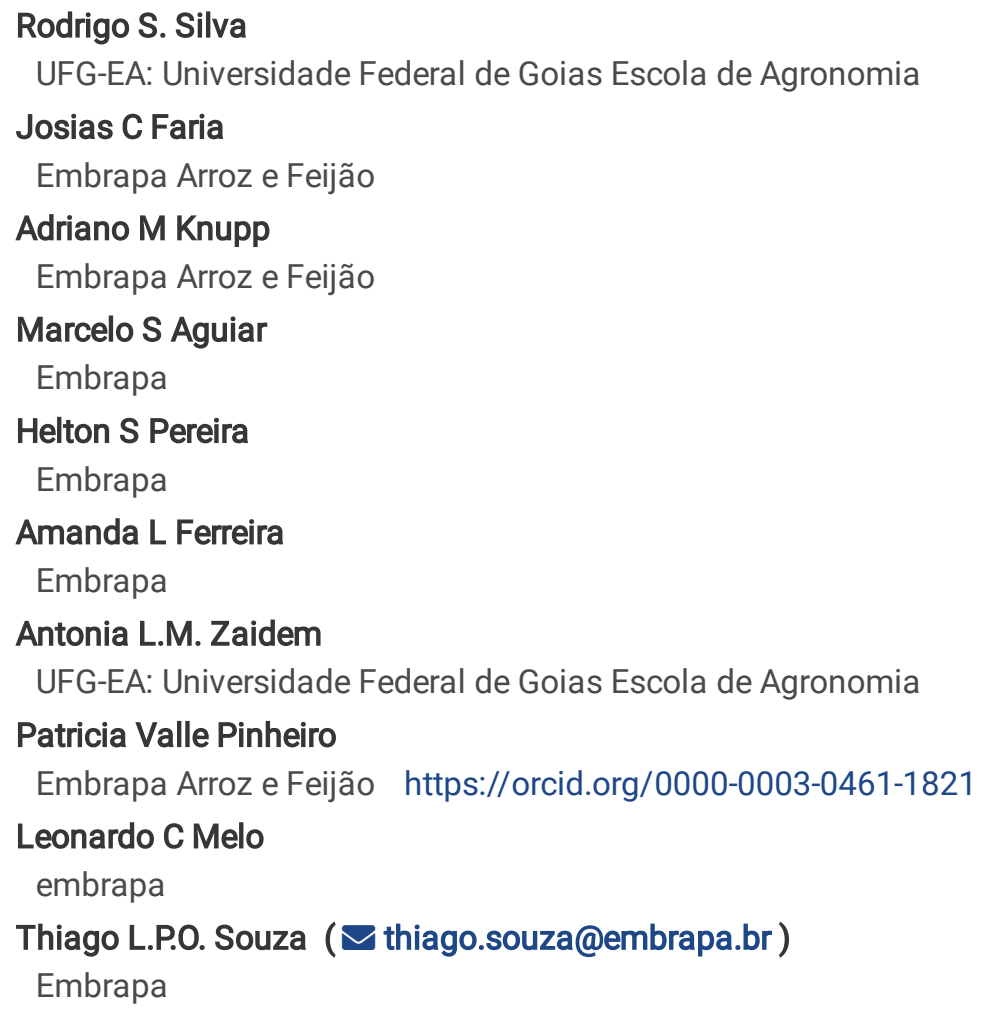




\section{Abstract}

The most important viruses infecting common bean (Phaseolus vulgaris L.) in Brazil are BCMV, BGMV and CPMMV, the last two transmitted by the whitefly Bemisia tabaci, occurring simultaneously and causing severe yield losses. Genetically modified progenies of common bean, from carioca market class and multiple virus resistance (BCMV, BGMV and CPMMV), have been developed using conventional breeding and molecular tools. Agronomic performance and virus disease severity (VS) evaluated in two field trials, selected 39 elite progenies out of 477. Molecular analyses identified the presence of BCMV and BGMV resistance alleles in plants. CPMMV resistance was measured on mechanically inoculated plants using a VS scoring scale. Among the lowest VS average scores, five progenies showed resistance to BCMV, BGMV and CPMMV, and upright plant architecture, resistance to plant lodging and carioca market class grains, presenting potential to be developed into a new transgenic cultivar, with multiple virus resistance. Additionally, the resistant progenies may also contribute to reduce virus spread in the field, as they were a less efficient inoculum source of CPMMV in insect transmission assays.

\section{Introduction}

Common bean (Phaseolus vulgaris L.) is the most directly consumed legume worldwide. This crop has a social and economic impact, its grain being an excellent source of proteins, minerals, fibers and vitamins. In addition, it has a wide geographic distribution, being cultivated mainly in countries in Latin America, Africa and Asia (Brigide et al., 2014; Martins et al., 2016; Yi et al., 2016). In Brazil, the common bean crop is grown in most states, by small, medium and large farmers, which use different technological levels (L. C. Faria et al., 2013; Martins et al., 2016; L. C. Melo et al., 2017). The country is the world's largest producer and consumer of common bean (FAOSTAT, 2020). In the 2018/19 harvest, Brazil produced approximately 1.88 million tons of common bean in 1.31 million hectares, with an average yield of $1.44 \mathrm{~kg} \mathrm{ha}^{-1}$ (Embrapa Arroz e Feijão, 2019). The average per capita consumption in Brazil is approximately $17.0 \mathrm{~kg} /$ person/year (Embrapa Arroz e Feijão, 2019), with national preference for grains from the carioca market class (around 70\% of consumption), followed by black beans (20\%), and other commercial classes (10\%) (Anderson et al., 2016; Barili et al., 2016; Barros \& Prudencio, 2016; L. C. Faria et al., 2013, 2014).

Despite the genetic progress obtained in the crop yield in recent years, around $17.4 \mathrm{~kg} \mathrm{ha}^{-1}$ year increase for carioca beans (L. C. Faria et al., 2013), common bean still presents grain yields below their productive potential (L. C. Faria et al., 2013, 2014). One of the factors that compromises the quality and, above all, the grain yield, is the large number of diseases that affect the crop (Assefa et al., 2019; Meziadi et al., 2016; Miklas et al., 2006), with emphasis on virus diseases (Alves-Freitas et al., 2019; J. Faria et al., 2016; Meziadi et al., 2016; Souza et al., 2018). Among the most important virus diseases of common beans in Brazil, there is the bean common mosaic virus (BCMV; family Potyviridae; genus Potyvirus) (Melotto et al., 1996; Meziadi et al., 2016), the bean golden mosaic virus (BGMV; family Germiniviridae; genus Begomovirus) (Bonfim et al., 2007; J. Faria et al., 2016; Souza et al., 2018) and the cowpea mild mottle virus (CPMMV; family Betaflexiviridae; genus Carlavirus). These last two viruses are transmitted by the whitefly (Bemisia tabaci; Hemiptera: Aleyrodidae) (Costa et al., 1983; J. Faria et al., 2016; Marubayashi et al., 2010) and can occur simultaneously in mixed infections (Alves-Freitas et al., 2019; J. Faria et al., 2016). A low rate of seed transmission of different CPMMV isolates was reported for some cultivars of soybean, cowpea and common bean (Iwaki et al., 1982; Jeyanandarajah \& Brunt, 1993; Thouvenel et al., 1982). Among the viruses transmitted by B. tabaci, Begomoviruses stand out, being the most widely disseminated and harmful to agriculture (Chen et al., 2016), due to the damage caused.

BGMV is currently the main virus that affects beans in Brazil, causing yield losses of up to 100\% (J. Faria et al., 2016; Souza et al., 2018). A rough estimate is that approximately 200,000 ha are made unfeasible annually for the cultivation of common bean in Brazil due to the occurrence of BGMV (Souza et al., 2018). The transgenic cultivar BRS FC401 RMD, immune to BGMV, carrying the transgene event Embrapa event 5.1 (RMD technology - short for resistance to the golden mosaic disease), has been developed by EMBRAPA, as a promising tool to mitigate this problem (Bonfim et al., 2007; Dinon et al., 2012). This cultivar also presents natural resistance to BCMV (gene ), but it is susceptible to CPMMV, as its both parents (J. Faria et al., 2016; Souza et al., 2018). Although CPMMV was first described in the country naturally infecting common beans (cv. Jalo) in 1979 (Costa et al., 1983), it has been considered as a minor disease issue in common beans.

CPMMV symptoms in common bean are a less pronounced mosaic, accompanied or not by leaf deformation, which can evolve into a more prominent crinkling in the leaves depending on the plant genotype (Alves-Freitas et al., 2019; J. Faria et al., 2016). Such symptoms are supplanted by the most severe symptoms of BGMV in mixed infections (J. Faria et al., 2016; Souza et al., 2018). As

Page $2 / 22$ 
CPMMV is the causal agent of soybean stem necrosis (Marubayashi et al., 2010), soybean is the main host of this virus, due to its wider dispersion in the country (Cheruku et al., 2017; J. Faria et al., 2016). However, in recent years, high incidence and distribution of CPMMV have also been registered in important common bean growing regions in Brazil (J. Faria et al., 2016), especially in Central Brazil, which has made CPMMV a pathogen of economic importance for the crop. Sources of natural or native resistance to CPMMV were identified in the carioca market class of common bean cultivars in evaluations carried out at Embrapa Arroz e Feijão (unpublished data).

Advances in genomic research have allowed the development of informative molecular markers, adding greater efficiency and speed to genetic improvement programs and making them more competitive. One of the most widely used resources for variety development has been marker-assisted backcrossing, helping to incorporate alleles of interest in elite lines, reducing the number of generations and genotypes throughout the cycles (Patroti et al., 2019). Regarding common bean, genome sequencing (Vlasova et al., 2016), the identification of thousands of SNP markers (Lobaton et al., 2018) and the development of fine genetic mapping studies (Gil et al., 2019) have contributed for countless molecular resources available to the scientific community. In this scenario, selection assisted by markers, has increasingly become viable and accessible, being integrated into the routine of common bean breeding programs (Assefa et al., 2019; Souza et al., 2018). Here, we report the development of elite genetically modified progenies of common bean, with carioca market class grains and multiple resistance to viruses (BCMV, BGMV and CPMMV). Regarding CPMMV, the resistant lines also contributed to reduce the transmission of the virus and the severity of symptoms in transmission assays.

\section{Materials And Methods}

\section{Genetic material}

For the development of elite common bean progenies with multiple resistance to viruses, the cultivars BRS Estilo and BRS Sublime were used as recurrent parents. These cultivars belong to the carioca market class, with high yield potential and standard type grains with high commercial quality, as well as plants of upright architecture and adapted to direct mechanical harvesting. BRS Estilo is one of the most cultivated commercial cultivars in Brazil in non-irrigated areas, according to periodic surveys carried out by Embrapa with the productive sector (unpublished data). BRS Sublime has horizontal resistance to angular leaf spot, which is an important disease for the crop, especially during the dry growing season. Both cultivars have moderate natural or native resistance to CPMMV. In addition, they are resistant to BCMV (L. C. Melo et al., 2010), but are susceptible to BGMV (Wendland et al., 2018).

Carioca market class lines CNFCT 16206 and CNFCT 16207 have the transgene from Embrapa 5.1 event that confers immunity to BGMV (RMD Technology), being also resistant to BCMV, but susceptible to CPMMV (J. Faria et al., 2016; Souza et al., 2018). The line CNFCT 16206 was used as donor parent of the Embrapa 5.1 event in all crosses and backcrosses and the line CNFCT 16207 was used for the multiplication of the CPMMV isolate for mechanical inoculations (isolate CPMMV: BR: GO: 14 - GenBank MK202583) (Alves-Freitas et al., 2019). The line CNFCT 16207 was also used as a susceptible control in the evaluation tests for reaction to CPMMV (Souza et al., 2016, 2018). Two common bean cultivars which present high seed yield were used as controls: BRS FC402, resistance to fusarium wilt and anthracnose (L. C. Melo et al., 2017) and BRS FC401 RMD, which is immune to the BGMV (Souza et al., 2018). Both cultivars have seeds in the carioca market class and resistance to BCMV, however they are susceptible to CPMMV.

\section{Marker-assisted selection (MAS)}

Plant genomic DNA from parental and progeny lines was extracted from leaf tissue samples using the CTAB method adapted from Doyle and Doyle (1990). To identify the presence of the transgene from event Embrapa 5.1 the molecular marker associated with the gene ahas was used (Dinon et al., 2012). The presence of gene I, which confers resistance to BCMV (Meziadi et al., 2017), was identified using the SCAR SW13 marker (Melotto et al., 1996). The amplification of these loci was performed by loco-specific PCR using TaqMan hydrolysis probes (ThermoFisher). The probes were designed using the Primer Express ${ }^{\mathrm{TM}}$ software (ThermoFisher).

The analysis of backcrosses assisted by markers, in the generations $\mathrm{BC}_{3} \mathrm{~F}_{1}, \mathrm{BC}_{4} \mathrm{~F}_{4: 5}$ and $\mathrm{BC}_{3} \mathrm{~F}_{5: 6}$ (Figure 1) was performed using a set of 24 SSR markers, as described by Morais et al. (2016). In the $\mathrm{BC}_{4} \mathrm{~F}_{4: 7}$ and $\mathrm{BC}_{3} \mathrm{~F}_{5: 8}$ (Figure 1) and in the $\mathrm{F}_{3: 7}$ and $\mathrm{F}_{4: 7}$ generations (Figure 2), the analysis of genetic similarity followed by the selection of plants closest to the recurrent parent was performed using 275 genotyped SNP markers on the Sequenom Technology Core platform (RAPID Genomics, USA). The analysis of genetic similarity, using the average Euclidean distance, was conducted using the GENES program (Cruz, 2013), from which the progenies with the largest portion of the recurrent parental genome were recovered.

Page $3 / 22$ 


\section{Crosses and progeny assessment}

Artificial crossings were carried out in a greenhouse, at Embrapa Arroz e Feijão, in Santo Antônio de Goiás, Goiás, Brazil. The transgenic line CNFCT 16206 (RMD) was used as a male parent in all crosses. Initially BRS Estilo was crossed with CNFCT 16206. After identifying the presence of the transgene by PCR (Bonfim et al., 2007; Dinon et al., 2012), the F1 hybrids were backcrossed with BRS Estilo (recurrent parent), in four cycles of consecutive backcrosses (BC). In all BC cycles, the presence of the transgene was verified by event-specific PCR. The genetic similarity of $\mathrm{BC}_{3} \mathrm{~F}_{1}$ plants to the recurrent parent was determined by backcross analysis assisted by molecular markers, using a set of 24 microsatellite markers (SSR), as previously described (Morais et al., 2016). From the $\mathrm{BC}_{3} \mathrm{~F}_{2}$ or $\mathrm{BC}_{4} \mathrm{~F}_{2}$ generations on, the following generations were advanced using the Single Seed Descend (SSD) method to $\mathrm{BC}_{4} \mathrm{~F}_{4}$ and $\mathrm{BC}_{3} \mathrm{~F}_{5}$. In these generations the plants were harvested individually and, thus, the generations $\mathrm{BC}_{4} \mathrm{~F}_{4: 5}$ and $\mathrm{BC}_{3} \mathrm{~F}_{5: 6}$ were obtained. Then, the plants were selected via PCR for the Embrapa 5.1 event (Bonfim et al., 2007; Dinon et al., 2012) and for the greater genetic similarity with the recurrent parent, and conducted individually to obtain the $\mathrm{BC}_{4} \mathrm{~F}_{4: 6}$ and $\mathrm{BC}_{3} \mathrm{~F}_{5: 7}$ generations (Figure 1).

Crosses were also performed between plants of the cultivar BRS Sublime and plants $\mathrm{BC}_{3} \mathrm{~F}_{1}$ (BRS Estilo $\times$ CNFCT 16206) (Figure 2). The F1 plants generated were evaluated for the presence of the Embrapa 5.1 event using PCR (Bonfim et al., 2007; Dinon et al., 2012). From the $F_{2}$ generation on, the following generations were advanced using the SSD method, in a greenhouse, until the $F_{4}$ generation. The individual plants were selected, harvested and conducted until obtaining the generations $F_{4: 6}$ and $F_{3: 6}$ (Figure 2).

Progenies obtained from individual plants selected from the two populations (Figures 1 and 2) were evaluated in a field experiment, at the winter growing season/2016, at Embrapa Arroz e Feijão, for their reaction to CPMMV and other diseases. A total of 477 progenies were evaluated, along with the conventional controls BRS FC402 and BRS Estilo and the transgenic control BRS FC401 RMD, in $2.0 \mathrm{~m}$ long rows, spaced by $0.45 \mathrm{~m}$, with 10 seeds per meter and a control row interspersed for every 10 progenies, without replications, totaling 525 plots, in which 48 were control lines. For the evaluation of the virus disease severity (VS), a scoring scale from 1 to 9 was used (L. Melo, 2009), where 1 is the score attributed to resistant plots and 9 to plots with susceptible plants with virus disease symptoms that affect seed yield. The elite progenies with the best performance were selected for further evaluations of agronomic performance in field and greenhouse experiments.

\section{Agronomic Performance Evaluation}

Two experiments were carried out, in the rainy season/2016 (sowing in December) and in the dry season/2017 (sowing in March), for the evaluation of agronomic performance. A total of 39 elite progenies selected in the previous stage and three controls (BRS Estilo, BRS FC402 and BRS FC401 RMD) were evaluated. Among these 39 progenies, 10 were derived from the crossing BRS Estilo $\times$ CNFCT 16206, generations $\mathrm{BC}_{4} \mathrm{~F}_{4: 6}$ and $\mathrm{BC}_{3} \mathrm{~F}_{5: 7}$ (Figure 1), and 29 from the crossing BRS Sublime $\times$ BC3F1 (BRS Estilo $\times$ CNFCT 16206 $R M D$ ), generations $F_{4: 6}$ and $F_{3: 6}$ (Figure 2). The experiments were carried out using a randomized block design with three replicates, each plot with $6 \mathrm{~m}^{2}$ and density of 10-12 plants/m. The plots were conducted using the recommended management for the cultivation of beans (Arf et al., 2015), however, without the control of diseases and insect pests. The following variables were evaluated: seed yield in $\mathrm{kg} \mathrm{ha}^{-1}$, corrected at 13\% humidity; 100-seed mass, in g, and seed appearance (scores 1 to 5): 1, commercial standard for carioca market class (light beige seeds with light brown stripes, opaque and not shiny); 5 , lowest commercial quality or other market class. (Barili et al., 2016; Ramalho et al., 2012). Plant architecture (PA), Tolerance to Lodging (TL) and Virus disease Severity (VS) were evaluated at the end of the crop season. For PA and TL a scoring scale from 1 to 9 was used, where 1 refers to lines suitable for mechanized harvesting (short guides, high pods, closer branches, and without bedding) and 9, lines that are unable to be mechanically harvested (long guides, low pods, open branches, and lodged plants) (L. Melo, 2009). To evaluate VS, the natural occurrence of the virus diseases was assessed based on a scoring scale of disease severity, where $1=$ no symptoms and $9=$ plot with $80-100 \%$ of plant with disease symptoms, or $60-100 \%$ of infected tissue (L. Melo, 2009). BRS Estilo and BRS FC402 were used as the controls for BGMV infection; BRS FC401 RMD was used as the control for CPMMV infection.

\section{Genetic and Statistical Analysis for Agronomic Traits}

Analysis of individual variances (ANOVA) were estimated for all traits, in each environment, using the $F$-test. The joint analysis was also performed for all traits. Progeny and environment effects were considered fixed. The averages were compared using the ScottKnott test, at $5 \%$ probability (Scott \& Knott, 1974). The experimental precision was also estimated through the selection accuracy (SA), as described (Resende \& Duarte, 2007). Statistical analyses were performed using the GENES statistical software (Cruz, 2013).

Page $4 / 22$ 


\section{Response to CPMMV infection at greenhouse}

Superior progenies, within the 39 progenies selected in the field experiments, were harvested individually and, thus, 20 plants per family, were grown in a greenhouse. Individual leaf tissue samples were collected 20 days after planting for DNA extraction and genotyping for the presence of resistance alleles (gene / for BCMV and gene ahas for the Embrapa 5.1 transgene event).

The individual plants were mechanically inoculated at eight days after sowing with a crude extract prepared by grinding leaves from CPMMV infected plants (isolate CPMMV: BR: GO: 14 - GenBank MK202583) in 0.1 M phosphate buffer containing sodium sulfite, added of a pinch of carborundum (Alves-Freitas et al., 2019; Cheruku et al., 2017). The cultivars BRS Estilo and BRS Sublime (Figures 1 and 2), BRS FC401 RMD and the line CNFCT 16207 were used as controls. At 35 days after inoculation, all plants were individually assessed for the severity of CPMMV symptoms, using a scoring scale from 1 to 9 , with $1=$ no symptoms and $9=$ plants with severe mosaic and/or crinkling leaf symptoms. Plants with no symptoms or showing a light mosaic or even a mosaic with light leaf deformations were considered resistant (grades 1, 2 and 3, respectively). Plants with severe mosaic, with or without leaf deformations, severe leaf deformations or with prominent crinkling in most leaves, were considered susceptible (4 or higher).

\section{CPMMV transmission in resistant common bean lines}

Greenhouse and field observations indicate that CPMMV can still replicate in the resistant progenies. Therefore, transmission assays were carried out to test how the resistant lines (CNFCT 19119 and CNFCT 19120, corresponding to the 422-39.1 and 554-15.1 progenies, respectively, Table 4), behave as inoculum source of CPMMV. In each experiment, eight-day old plants from each line (CNFCT 19119 or CNFCT 19120), BRS Sublime (resistant control) and BRS FC401 RMD (susceptible control) were mechanically inoculated with CPMMV, as previously described, to be used as CPMMV inoculum sources. Twenty days after inoculation, systemic infection was confirmed by RT-PCR. Total RNA was extracted using the Promega SV Total RNA isolation system, and cDNA was synthesized using the Promega Go-script reverse transcription system, with oligo-dT primers. PCR reactions were performed using CPMMV specific primers CPMMV-cpF (5'- GCATGTGGCTGAGGTTCT -3') and CPMMV-cpR (5'- AGGCGGCAATCACTGAATCA -3'). Then, virus-free adult whiteflies were transferred to the CPMMV-infected plants for virus acquisition for 1 hour. After that, insects were carefully transferred to three groups of test plants, one from each bean line (CNFCT 19119 or CNFCT 19120, BRS Sublime and BRS FC401 RMD) in individual cages (5 insects/plant and 40 replicates per treatment), for a $2 \mathrm{~h}$ inoculation period. After 20 days, virus disease severity was evaluated using a 1-4 scoring scale for the level of symptoms ( $1=$ none, $2=$ light, $3=$ moderate and $4=$ strong). The homocedasticity Levene test and residual normality Kolmogorov-Smirnov test were performed for data analysis. The inoculum sources were compared using the Pearson's Chi-square test for the proportion of plants showing each symptom score (category). Fixing the inoculum source as one the resistant lines (CNFCT 19119 or CNFCT 19120), the proportions of plants within each grade of the scoring scale were compared using the Equality of Proportions Hypothesis test $(p<0.05)$. 
Table 4

Summary of the combined analysis of variance for the agronomic traits seed yield, 100-seed mass (100M), plant architecture (PA), tolerance to lodging (TL), seed appearance (SaP) and virus disease severity (VS), evaluated in 39 common bean elite progenies and three controls in Santo Antônio de Goiás, Goiás, Brazil, during the rainy growing season/2016 and dry growing season/2017.

\begin{tabular}{|c|c|c|c|c|c|c|c|}
\hline \multirow[t]{2}{*}{ Source of variation } & \multirow[t]{2}{*}{ df } & \multicolumn{2}{|l|}{ Yield } & \multicolumn{2}{|c|}{$100 \mathrm{M}$} & \multicolumn{2}{|l|}{ PA } \\
\hline & & MS & $P$ value & MS & $P$ value & MS & $P$-value \\
\hline Treatments $(T)$ & 41 & 218862 & 0,001 & 4,42 & 0,001 & 1,82 & 0,001 \\
\hline Progenies $(P)$ & 38 & 200082 & 0,001 & 4,37 & 0,001 & 0,66 & 0,060 \\
\hline Controls (C) & 2 & 638407 & 0,002 & 3,95 & 0,001 & 2,88 & 0,002 \\
\hline T vs Environment (E) & 41 & 242568 & 0,001 & 1,82 & 0,013 & 0,68 & 0,043 \\
\hline Pvs E & 38 & 244596 & 0,001 & 1,89 & 0,010 & 0,47 & 0,439 \\
\hline Cvs E & 2 & 42415 & 1,000 & 1,18 & 0,233 & 0,88 & 0,148 \\
\hline Residue & 168 & 95341 & - & 0,80 & - & 0,46 & - \\
\hline Overall mean & - & - & 1118 & - & 22,90 & - & 4,60 \\
\hline Progeny mean & - & - & 1123 & - & 22,95 & - & 4,49 \\
\hline Control mean & - & - & 1048 & - & 22,30 & - & 6,11 \\
\hline \multirow[t]{2}{*}{ Source of variation } & \multirow[t]{2}{*}{$\mathrm{df}$} & \multicolumn{2}{|l|}{ TL } & \multicolumn{2}{|l|}{ SaP } & \multicolumn{2}{|l|}{ vs } \\
\hline & & MS & $P$-value & MS & $P$-value & MS & $P$-value \\
\hline Treatments $(T)$ & 41 & 2,99 & 0,001 & 1,56 & 0,001 & 3,63 & 0,001 \\
\hline Progenies $(P)$ & 38 & 1,18 & 0,014 & 1,59 & 0,001 & 1,79 & 0,001 \\
\hline Controls (C) & 2 & 10,05 & 0,001 & 1,55 & 0,009 & 0,22 & 1,000 \\
\hline T vs Environment (E) & 41 & 0,93 & 0,114 & 0,25 & 1,000 & 1,25 & 0,001 \\
\hline Pvs E & 38 & 0,86 & 0,193 & 0,24 & 1,000 & 1,13 & 0,002 \\
\hline C vs E & 2 & 2,38 & 0,003 & 0,22 & 1,000 & 0,88 & 0,220 \\
\hline Residue & 168 & 0,71 & - & 0,32 & - & 0,58 & - \\
\hline Overall mean & - & - & 4,00 & - & 2,07 & - & 3,68 \\
\hline Progeny mean & - & - & 3,86 & - & 2,06 & - & 3,52 \\
\hline Control mean & - & - & 5,72 & - & 2,22 & - & 5,72 \\
\hline \multicolumn{8}{|c|}{$\begin{array}{l}\text { df, degrees of freedom; MS: mean square; Yield, seed yield in } \mathrm{kg} \mathrm{ha}^{-1} \text {, corrected to } 13 \% \text { moisture content; } 100 \mathrm{M}, 100 \text {-seed mass in } \\
\text { g.; Plant architecture (PA) and tolerance to lodging (TL) (scores } 1 \text { to } 9 \text { ): } 1 \text {, lines suitable for mechanized harvesting (short guides, } \\
\text { high pods, closer branches, and without bedding); } 9 \text {, lines that are unable to be mechanically harvested (long guides, low pods, } \\
\text { open branches, and lodged plants); SaP, seed appearance (scores } 1 \text { to } 5 \text { ): } 1 \text {, commercial standard for carioca market class; } 5 \text {, } \\
\text { lowest commercial quality or other market class; VS, Virus disease severity (scores } 1 \text { to } 9 \text { ): } 1 \text { = no symptoms and } 9=\text { plot with } \\
80-100 \% \text { of plant diseases, or } 60-100 \% \text { of infected tissues (Melo, } 2009 \text { ); BGMV - bean golden mosaic virus, evaluated in the } \\
\text { conventional controls (BRS Estilo and BRS FC402) and CPMMV - cowpea mild motle virus, evaluated in the elite progenies and } \\
\text { in the transgenic control (BRS FC401 RMD). }\end{array}$} \\
\hline
\end{tabular}

\section{Results And Discussion}

Thirty nine out of 477 elite progenies have been selected in the field experiments based on their agronomic performance, considering the best scores for virus disease severity (VS), seed yield, plant architecture (PA), tolerance to lodging (TL), 100-seed mass (100M) and seed appearance (SaP) (Table 1). Overall, the VS average among the selected progenies ranged from 2.3 to 5.8 , confirming there is high genetic variability for the resistance to viruses under field conditions (Table 1). As expected, conventional controls (BRS Estilo and BRS FC402) were susceptible to BGMV, with a virus disease severity (VS) average of 5.8 (Table 1). Because CPMMV symptoms 
can be totally suppressed by the symptoms of BGMV (Alves-Freitas et al., 2019; J. Faria et al., 2016; Souza et al., 2018), it was not possible to distinguish the severity of CPMMV symptoms from the BGMV symptoms in the conventional controls, which are not resistant to BGMV. Thus, VS average in the elite progenies, regarding CPMMV, were compared only to that of the transgenic control (BRS FC 401 RMD), being significantly lower (Table 1). Twelve out of the 39 elite progenies (31\%) had average scores for VS $\leq 3.0$ (Table 1), indicating that they were highly resistant/tolerant to the virus diseases, including CPMMV. Sixteen out of 39 elite progenies (41\%) showed average seed yield statistically equal to the transgenic control, and among those, there were 8 of the 12 elite progenies selected as the most tolerant to CPMMV (VS $\leq 3.0$ ) (Table 1). The superiority of the elite progenies, along with the transgenic control, in comparison with the conventional controls, corroborates the results reported by Souza et al. (2018), indicating that the presence of the Embrapa 5.1 transgene increased seed yield stability in elite GM common bean lines. 
Table 1

Average virus disease severity (VS), agronomic traits and quality of grains, evaluated in 39 common bean elite progenies and three control cultivars, in Santo Antônio de Goiás, Goiás, Brazil, during the rainy growing season/2016 and dry season/2017.

\begin{tabular}{|c|c|c|c|c|c|c|}
\hline Progeny ID & Yield & $100 \mathrm{M}$ & PA & $\mathrm{TL}$ & SaP & VS \\
\hline $356-27.1$ & $1664 a$ & $23,9 a$ & $4,3 a$ & $3,6 a$ & $2,1 b$ & $2,8 a$ \\
\hline $477-4.1$ & $1459 a$ & $23,1 b$ & $4,3 a$ & $3,6 a$ & $2,5 b$ & $3,8 b$ \\
\hline BRS FC401RMD & $1387 a$ & $23,2 b$ & $6,6 c$ & $7,1 \mathrm{c}$ & $2,3 b$ & $5,5 c$ \\
\hline $356-5.1$ & $1359 a$ & $21,8 \mathrm{c}$ & $4,3 a$ & $3,3 a$ & $1,6 a$ & $2,5 a$ \\
\hline 398-3.1 & $1357 a$ & $22,0 \mathrm{c}$ & $4,8 a$ & $4,8 b$ & $2,6 c$ & $3,0 a$ \\
\hline 184-16.1 & $1348 a$ & $23,1 b$ & $4,3 a$ & $4,0 a$ & $1,6 a$ & $3,0 a$ \\
\hline $389-8.1$ & $1335 a$ & $22,9 b$ & $4,1 a$ & $3,8 a$ & $2,0 a$ & $4,0 b$ \\
\hline 356-3.1 & $1292 a$ & $23,2 b$ & $4,3 a$ & $3,6 a$ & $1,8 a$ & $3,0 a$ \\
\hline 211-1.1 & $1288 a$ & $23,8 a$ & $4,5 a$ & $4,0 a$ & $1,1 \mathrm{a}$ & $3,6 b$ \\
\hline $195-10.1$ & $1275 a$ & $22,3 c$ & $5,3 b$ & $5,1 b$ & $1,8 a$ & $3,8 b$ \\
\hline $398-14.1$ & $1275 a$ & $24,3 a$ & $4,0 a$ & $4,0 a$ & $1,6 a$ & $3,0 a$ \\
\hline $422-39.1$ & $1220 a$ & $22,9 b$ & $4,8 a$ & $4,3 a$ & $1,5 a$ & $2,8 a$ \\
\hline $185-10.1$ & $1217 a$ & $23,7 a$ & $4,5 a$ & $3,1 a$ & $2,0 a$ & $3,6 b$ \\
\hline 336-3.1 & $1211 a$ & $21,5 c$ & $4,5 a$ & $4,0 a$ & $2,3 b$ & $2,8 a$ \\
\hline 183-33.1 & $1183 a$ & $23,5 b$ & $4,6 a$ & $4,1 \mathrm{a}$ & $1,8 a$ & $3,8 b$ \\
\hline $336-14.1$ & $1179 a$ & $21,2 \mathrm{c}$ & $4,0 a$ & $4,1 a$ & $2,8 \mathrm{c}$ & $4,0 \mathrm{~b}$ \\
\hline $477-10.1$ & $1165 a$ & $22,5 c$ & $5,0 a$ & $3,8 a$ & $2,1 b$ & $4,1 b$ \\
\hline 198-29.1 & $1138 b$ & $23,9 a$ & $4,0 a$ & $3,3 a$ & $1,5 a$ & $4,3 b$ \\
\hline 295-10.1 & $1122 b$ & $22,0 \mathrm{c}$ & $4,0 a$ & $3,8 a$ & $1,6 a$ & $3,6 b$ \\
\hline 477-9.1 & $1093 b$ & $22,8 b$ & $4,0 a$ & $3,5 a$ & $1,5 a$ & $4,3 b$ \\
\hline 201-16.1 & $1092 b$ & $23,9 a$ & $4,1 a$ & $4,1 a$ & $1,5 a$ & $3,8 b$ \\
\hline $367-8.1$ & $1079 b$ & $22,8 b$ & $4,8 a$ & $4,3 a$ & $1,5 a$ & $3,6 b$ \\
\hline $184-12.1$ & $1074 b$ & $22,7 b$ & $5,0 a$ & $4,6 b$ & $2,0 a$ & $2,8 a$ \\
\hline $417-22.1$ & $1072 b$ & $24,5 a$ & $4,1 \mathrm{a}$ & $3,5 a$ & $1,5 a$ & $2,5 a$ \\
\hline
\end{tabular}

Yield, seed yield in $\mathrm{kg}$ ha-1, corrected to $13 \%$ moisture content.

$100 \mathrm{M}, 100$-seed mass in $\mathrm{g}$.

Plant architecture (PA) and tolerance to lodging (TL) (scores 1 to 9): 1, lines suitable for mechanized harvesting (short guides, high pods, closer branches, and without bedding); 9 , lines that are unable to be mechanically harvested (long guides, low pods, open branches, and lodged plants).

SaP, seed appearance (scores 1 to 5): 1, commercial standard for carioca market class; 5 , lowest commercial quality or other market class.

VS, Virus disease severity (scores 1 to 9 ): $1=$ no symptoms and $9=$ plot with $80-100 \%$ of plant diseases, or $60-100 \%$ of infected tissues (Melo, 2009).

BGMV - bean golden mosaic virus, evaluated in the conventional controls (BRS Estilo and BRS FC402) and CPMMV - cowpea mild motle virus, evaluated in the elite progenies and in the transgenic control (BRS FC401 RMD).

Means followed by the same letter in the table columns are not significantly different according to the Scott-Knott method at $5 \%$ probability. 


\begin{tabular}{|c|c|c|c|c|c|c|}
\hline Progeny ID & Yield & $100 \mathrm{M}$ & PA & $\mathrm{TL}$ & $\mathrm{SaP}$ & VS \\
\hline $520-17.1$ & $1069 b$ & $24,5 a$ & $4,6 a$ & $4,0 a$ & $2,6 c$ & $3,6 b$ \\
\hline $450-29.1$ & $1058 b$ & $22,4 \mathrm{c}$ & $4,5 a$ & $3,8 a$ & $2,3 b$ & $3,6 b$ \\
\hline $224-24.1$ & $1046 b$ & $23,6 a$ & $4,5 a$ & $4,1 a$ & $2,5 b$ & $4,1 b$ \\
\hline $389-14.1$ & $1023 b$ & $23,4 b$ & $4,1 a$ & $3,3 a$ & $1,6 a$ & $3,6 b$ \\
\hline BRS Estilo & $1022 b$ & $21,6 c$ & $5,3 b$ & $4,6 b$ & $1,6 a$ & $5,8 c$ \\
\hline $554-27.1$ & $1005 b$ & $22,8 b$ & $4,5 a$ & $3,5 a$ & $3,0 c$ & $3,6 b$ \\
\hline $362-15.1$ & $984 b$ & $22,9 b$ & $4,6 a$ & $4,3 a$ & $2,6 c$ & $3,6 b$ \\
\hline 398-15.1 & $984 b$ & $23,0 b$ & $4,1 a$ & $3,5 a$ & $1,5 a$ & $4,0 b$ \\
\hline 554-19.1 & $956 b$ & $21,7 c$ & $4,8 a$ & $3,6 a$ & $3,0 \mathrm{c}$ & $3,6 b$ \\
\hline $184-7.1$ & $943 b$ & $22,1 \mathrm{c}$ & $4,5 a$ & $3,8 a$ & $1,8 a$ & $4,1 b$ \\
\hline $477-3.1$ & $916 b$ & $23,4 b$ & $4,5 a$ & $3,6 a$ & $2,8 \mathrm{c}$ & $4,1 b$ \\
\hline $520-10.1$ & $916 b$ & $22,6 b$ & $5,1 b$ & $4,0 a$ & $1,8 \mathrm{a}$ & $3,6 b$ \\
\hline $544-26.1$ & $898 b$ & $21,9 c$ & $4,5 a$ & $3,5 a$ & $3,1 c$ & $3,8 b$ \\
\hline $367-19.1$ & $898 b$ & $23,9 a$ & $4,5 a$ & $4,0 a$ & $1,8 a$ & $3,6 b$ \\
\hline $520-20.1$ & $890 b$ & $23,1 b$ & $4,5 a$ & $3,8 a$ & $2,3 b$ & $3,6 b$ \\
\hline 554-15.1 & $880 \mathrm{~b}$ & $22,7 b$ & $4,8 a$ & $3,5 a$ & $2,3 b$ & $2,8 a$ \\
\hline $554-23.1$ & $857 b$ & $21,5 c$ & $4,5 a$ & $3,0 a$ & $2,1 b$ & $2,3 a$ \\
\hline BRS FC402 & $736 b$ & $22,0 c$ & $6,3 c$ & $5,3 b$ & $2,6 c$ & $5,8 \mathrm{c}$ \\
\hline Total mean & 1118 & 22,90 & 4,58 & 3,96 & 2,04 & 3,64 \\
\hline Progeny mean & 1123 & 22,95 & 4,46 & 3,83 & 2,03 & 3,48 \\
\hline Control mean & 1048 & 22,30 & 6,06 & 5,66 & 2,16 & 5,70 \\
\hline
\end{tabular}

Yield, seed yield in kg ha-1, corrected to $13 \%$ moisture content.

$100 \mathrm{M}, 100$-seed mass in $\mathrm{g}$.

Plant architecture (PA) and tolerance to lodging (TL) (scores 1 to 9): 1, lines suitable for mechanized harvesting (short guides, high pods, closer branches, and without bedding); 9 , lines that are unable to be mechanically harvested (long guides, low pods, open branches, and lodged plants).

SaP, seed appearance (scores 1 to 5): 1, commercial standard for carioca market class; 5 , lowest commercial quality or other market class.

VS, Virus disease severity (scores 1 to 9 ): $1=$ no symptoms and $9=$ plot with $80-100 \%$ of plant diseases, or $60-100 \%$ of infected tissues (Melo, 2009).

BGMV - bean golden mosaic virus, evaluated in the conventional controls (BRS Estilo and BRS FC402) and CPMMV - cowpea mild motle virus, evaluated in the elite progenies and in the transgenic control (BRS FC401 RMD).

Means followed by the same letter in the table columns are not significantly different according to the Scott-Knott method at $5 \%$ probability.

Phenotypic and molecular analyses were applied to discriminate for the presence of resistance alleles in plants from the 12 selected progenies, after mechanical inoculation with CPMMV in a controlled environment. The dominant allele of the gene $I$, which confers resistance to $B C M V$, was detected in the 12 selected virus resistant progenies and in the controls (Table 2), using the SCAR SW13 marker. The line CNFCT 16206, used as the donor parent, presents a hypersensitivity reaction to the bean common mosaic necrosis 
virus (BCMNV), indicating the presence of gene / for resistance to BCMV (Souza et al., 2018). The transgene from the Embrapa 5.1 event, which confers resistance to the BGMV, was detected in 11 out of the 12 selected progenies. The successful transfer of the transgene to these 11 elite progenies, all resistant to BGMV, corroborates the previous agronomic and molecular characterization of the transgene (Aragão et al., 2013; J. C. Faria et al., 2014). The transgene is inherited in a 3:1 Mendelian segregation (J. C. Faria et al., 2014) with an intra-allelic relationship of complete dominance for the transgene and for the reaction to BGMV. A similar segregation pattern has been confirmed regarding the resistance to CPMMV in the cultivar BRS Sublime (J. C. Faria, unpublished data). Both recurrent parents, the cultivars BRS Estilo and Sublime are valuable sources of resistance and/or tolerance to CPMMV (J. C. Faria, unpublished data). In the present study, five out of 12 progenies (41\%) were considered resistant and/or tolerant to CPMMV, all five of which were also resistant to BGMV and BCMV (Table 2). Thus, progenies 184-12.1 (line CNFCT 19110), 356-5.1 (line CNFCT 19114), 398-3.1 (line CNFCT 19116), 417-22.1 (line CNFCT 19118) and 422-39.1 (line CNFCT 19119) showed multiple resistance to BCMV, BGMV and CPMMV viruses, in addition to other desirable agronomic traits, such as upright architecture, tolerance to lodging, and carioca market class seeds (Tables 1 and 2). Of the five progenies resistant to CPMMV, only the progeny 184-12.1 was derived from the cross between the cultivar BRS Estilo and the line CNFCT 16206. The others are from the cross (BRS Sublime $\times$ BRS Estilo GM) (Figures 1 and 2; Table 2). At this breeding stage, the progenies with multiple resistance to viruses were then considered as elite lines. 
Table 2

Phenotypic and molecular characterization of virus resistance in common bean elite progenies/lines and controls, evaluated in a greenhouse, in Santo Antônio de Goiás, Goiás, Brazil.

\begin{tabular}{|c|c|c|c|c|}
\hline Progeny ID & Line ID & $\begin{array}{l}\text { CPMMV } \\
\text { (Phenotyp }\end{array}$ & BGMV (Gene Ahas) $^{\mathrm{C}}$ & $\begin{array}{l}\text { BCMVd } \\
\text { (Gene I) }\end{array}$ \\
\hline $184-12.1$ & CNFCT 19110 & $\mathrm{RR}$ & $\mathrm{RR}$ & $\mathrm{RR}$ \\
\hline $184-16.1$ & CNFCT 19111 & Het & $\mathrm{RR}$ & $\mathrm{RR}$ \\
\hline 336-3.1 & CNFCT 19112 & Het & Het & $\mathrm{RR}$ \\
\hline $356-3.1$ & CNFCT 19113 & Het & $\mathrm{RR}$ & $\mathrm{RR}$ \\
\hline $356-5.1$ & CNFCT 19114 & $\mathrm{RR}$ & $\mathrm{RR}$ & $\mathrm{RR}$ \\
\hline $356-27.1$ & CNFCT 19115 & Het & $\mathrm{RR}$ & $\mathrm{RR}$ \\
\hline $398-3.1$ & CNFCT 19116 & $\mathrm{RR}$ & $\mathrm{RR}$ & $\mathrm{RR}$ \\
\hline $398-14.1$ & CNFCT 19117 & Het & $\mathrm{RR}$ & $\mathrm{RR}$ \\
\hline $417-22.1$ & CNFCT 19118 & $\mathrm{RR}$ & $\mathrm{RR}$ & $\mathrm{RR}$ \\
\hline $422-39.1$ & CNFCT 19119 & $\mathrm{RR}$ & $\mathrm{RR}$ & $\mathrm{RR}$ \\
\hline $554-15.1$ & CNFCT 19120 & Het & $\mathrm{RR}$ & $\mathrm{RR}$ \\
\hline $554-23.1 .1$ & CNFCT 19121 & Het & $\mathrm{RR}$ & $\mathrm{RR}$ \\
\hline CNFCT $16207^{\mathrm{e}}$ & & SS & $\mathrm{RR}$ & $\mathrm{RR}$ \\
\hline BRS FC401 RMD ${ }^{f}$ & & SS & $\mathrm{RR}$ & $\mathrm{RR}$ \\
\hline BRS Sublime & & $\mathrm{RR}$ & SS & $\mathrm{RR}$ \\
\hline BRS Estilo & & $\mathrm{RR}$ & SS & $\mathrm{RR}$ \\
\hline \multicolumn{5}{|c|}{$\begin{array}{l}\text { b Cowpea mild mottle virus; Mechanical inoculation of CPMMV (isolate CPMMV: BR: GO: } 14 \text { - GenBank MK202583) (Alves-Freitas } \\
\text { et al., 2019).. }\end{array}$} \\
\hline \multicolumn{5}{|c|}{ RR, homozygous resistant; Het, Heterozygous; SS, homozygous susceptible. } \\
\hline \multicolumn{5}{|c|}{ ` Bean golden mosaic virus; Marker assisted selection using gene ahas (Bonfim et al., 2007; Dinon et al., 2012). } \\
\hline \multicolumn{5}{|c|}{ d Bean common mosaic virus; Marker assisted selection using marker SCAR SW13 linked to gene /(Melotto et al., 1996). } \\
\hline \multicolumn{5}{|c|}{$\begin{array}{l}\text { e CNFCT 16207, common bean genetically modified line, resistant to the golden mosaic (Event Embrapa 5.1; RMD technology) } \\
\text { (Souza et al., 2018). }\end{array}$} \\
\hline \multicolumn{5}{|c|}{ fBRS FC401 RMD, common bean genetically modified commercial cultivar, resistant to the golden mosaic (RMD) } \\
\hline
\end{tabular}

Although CPMMV infection in the resistant lines primarily results in light symptoms, not affecting seed yield or other relevant agronomic traits, CPMMV replication is not suppressed in these common bean lines (Figure S1). We conducted whitefly CPMMV transmission assays using two of the resistant lines (CNFCT 19119 and CNFCT 19120), the tolerant cultivar BRS Sublime and the susceptible cultivar BRS FC401 RMD, as both inoculum sources and test plants. Figures 3A and 3B show the proportion of test plants in each grade of the scoring scale, by inoculum source. The results show that when the inoculum source of CPMMV was the resistant line CNFCT 19119 (Figure 3A), the majority of the infected plants were symptomless or presented only light symptoms, a significantly higher proportion than that observed for the other inoculum sources (BRS Sublime and BRS FC401 RMD) (Chi-square, $p<$ 0.05). Additionally, no plants with strong symptoms of the disease were observed, when the inoculum source was line CNFCT 19119. Remarkably, when the other resistant line, CNFCT 19120, was the inoculum source, over $80 \%$ of infected plants presented light virus 
disease symptoms (Figure 3B). Fixing the inoculum source as one of the resistant lines, the proportion of test plants without symptoms or presenting light symptoms was significantly higher when the test plants were also from one of the resistant lines (Figure 4). Likewise, a higher proportion of plants with moderate or strong symptoms was observed when the test plants were from a susceptible cultivar (BRS FC401 RMD). The reduced transmission of CPMMV, evidenced by the high proportion of plants presenting none or light symptoms in the transmission assays, indicates that these resistant lines represent a promising tool for reducing virus spread in the field, as well as virus disease symptoms. Similar results have been reported for the selection of cassava breeding lines with effective resistance to cassava brown streak viruses (CBSVs) and cassava mosaic begomoviruses (CMBs) (Mukiibi et al., 2019), which are also transmitted by $B$. tabaci, showing significantly lower severity, compared to the controls.

Besides the trait virus disease severity, elite progenies were selected in field experiments following the quality control usually applied for the selection of all other important agronomic traits in the Embrapa common bean breeding program. In the field experiments, the coefficients of variation (CV\%) ranged from 3.6 for 100 -seed mass (100M) to 28.1 for seed yield (Table 3), similar to another study selecting common bean lines for pathogen resistance (Pereira et al. 2019). Estimates of selection accuracy (SA) of progenies were high $(0.70 \leq \mathrm{SA} \otimes 0.90)$ for some traits (seed yield, $100 \mathrm{M}, \mathrm{SaP}$ and $\mathrm{VS})$, and moderate $(0.50 \leq \mathrm{SA} \otimes 0.70)$ for others (PA and TL) (Table 3). This indicates good experimental informativeness, similar to the SA values reported for VS of BGMV and CPMMV when the elite GM common bean lines were evaluated under field conditions (Souza et al., 2018). SA represents the best parameter to assess experimental precision when evaluating plant lines (Resende \& Duarte 2007), and also reflects environmental and genetic variations (Ramalho et al., 2012). The adequate experimental precision made it possible to discriminate the 39 elite progenies for all the agronomic performance traits, especially VS, in field conditions, which allowed to select the best lines with the highest virus resistance. 
Table 3

Summary of the analysis of individual variance for the agronomic traits evaluated in 39 common bean elite progenies and three control cultivars, in Santo Antônio de Goiás, Goiás, Brazil, in the rainy growing season/2016 and dry growing season/2017.

\begin{tabular}{|c|c|c|c|c|c|c|c|c|c|c|c|c|c|c|}
\hline \multirow{2}{*}{$\begin{array}{l}\text { Source of } \\
\text { variation }\end{array}$} & \multicolumn{14}{|c|}{ Rainy season/2016 } \\
\hline & df & Yield & & & $100 \mathrm{M}$ & & PA & & TL & & $\mathrm{SaP}$ & & VS & \\
\hline MS & & $\begin{array}{l}\mathrm{P} \text { - } \\
\text { value }\end{array}$ & MS & $\begin{array}{l}\text { P- } \\
\text { value }\end{array}$ & MS & $\begin{array}{l}\text { P- } \\
\text { value }\end{array}$ & MS & $\begin{array}{l}\mathrm{P} \text { - } \\
\text { value }\end{array}$ & MS & $\begin{array}{l}\text { P- } \\
\text { value }\end{array}$ & MS & P-value & & \\
\hline $\begin{array}{l}\text { Treatments } \\
(\mathrm{T})\end{array}$ & 41 & 313346 & & 0,001 & 2,42 & 0,001 & 1,79 & 0,001 & 2,04 & 0,001 & 1,14 & 0,001 & 2,51 & 0,001 \\
\hline $\begin{array}{l}\text { Progenies } \\
\text { (P) }\end{array}$ & 38 & 301774 & & 0,001 & 2,49 & 0,001 & 0,58 & 0,170 & 0,86 & 0,040 & 1,13 & 0,001 & 0,90 & 0,006 \\
\hline $\begin{array}{l}\text { Controls } \\
\text { (C) }\end{array}$ & 2 & 410146 & & 0,032 & 1,13 & 0,170 & 3,00 & 0,002 & 8,11 & 0,001 & 1,33 & 0,007 & 1,00 & 0,124 \\
\hline$P$ vs $C$ & 1 & 559489 & & 0,029 & 2,40 & 0,053 & 45,16 & 0,001 & 34,87 & 0,001 & 1,12 & 0,039 & 66,48 & 0,001 \\
\hline Residue & 82 & 114605 & & - & 0,62 & - & 0,45 & - & 0,54 & - & 0,25 & - & 0,46 & - \\
\hline $\begin{array}{l}\text { Overall } \\
\text { mean }\end{array}$ & - & - & & 1287 & - & 21,93 & - & 3,84 & - & 3,21 & - & 1,99 & - & 3,38 \\
\hline Mean $(P)$ & - & - & & 1306 & - & 21,97 & - & 3,67 & - & 3,06 & - & 1,96 & - & 3,17 \\
\hline Mean (C) & - & - & & 1047 & - & 21,43 & - & 6,00 & - & 5,11 & - & 2,33 & - & 6,00 \\
\hline CV(\%) & - & - & & 26,28 & - & 3,60 & - & 17,58 & - & 22,91 & - & 25,48 & - & 20,22 \\
\hline SA & - & - & & 0,78 & - & 0,86 & - & 0,50 & - & 0,61 & - & 0,87 & - & 0,70 \\
\hline
\end{tabular}

\begin{tabular}{|c|c|c|c|c|c|c|c|c|c|c|c|c|c|c|}
\hline \multirow{2}{*}{$\begin{array}{l}\text { Source of } \\
\text { variation }\end{array}$} & \multirow[t]{2}{*}{ GL } & & \multicolumn{12}{|c|}{ Yield. 100M PA TL SaP VS } \\
\hline & & & MS & $\begin{array}{l}\mathrm{P} \text { - } \\
\text { value }\end{array}$ & MS & $\begin{array}{l}\mathrm{P}- \\
\text { value }\end{array}$ & MS & $\begin{array}{l}\text { P- } \\
\text { value }\end{array}$ & MS & $\begin{array}{l}\text { P- } \\
\text { value }\end{array}$ & MS & $\begin{array}{l}\text { P- } \\
\text { value }\end{array}$ & MS & $\begin{array}{l}\mathrm{P}- \\
\text { value }\end{array}$ \\
\hline $\begin{array}{l}\text { Treatments } \\
\text { (T) }\end{array}$ & 41 & 148084 & & 0,002 & 3,82 & 0,001 & 0,71 & 0,007 & 1,88 & 0,007 & 0,67 & 0,008 & 2,38 & 0,001 \\
\hline $\begin{array}{l}\text { Progenies } \\
\text { (P) }\end{array}$ & 38 & 142904 & & 0,004 & 3,78 & 0,001 & 0,55 & 0,082 & 1,19 & 0,081 & 0,69 & 0,006 & 2,02 & 0,002 \\
\hline $\begin{array}{l}\text { Controls } \\
\text { (C) }\end{array}$ & 2 & 270676 & & 0,026 & 4,00 & 0,020 & 0,77 & 0,135 & 4,33 & 0,007 & 0,44 & 0,294 & 0,11 & 1,000 \\
\hline$P$ vs C & 1 & 99718 & & 0,240 & 4,95 & 0,026 & 6,98 & 0,001 & 23,21 & 0,001 & 0,02 & 1,000 & 20,44 & 0,001 \\
\hline Residue & 82 & 71401 & & - & 0,97 & - & 0,38 & - & 0,82 & - & 0,35 & - & 0,68 & - \\
\hline $\begin{array}{l}\text { Overall } \\
\text { mean }\end{array}$ & - & - & & 948,7 & - & 23,87 & - & 5,37 & - & 4,78 & - & 2,16 & - & 3,99 \\
\hline Mean $(P)$ & - & - & & 940,9 & - & 23,93 & - & 5,30 & - & 4,66 & - & 2,17 & - & 3,88 \\
\hline Mean (C) & - & - & & 1051 & - & 23,16 & - & 6,20 & - & 6,33 & - & 2,11 & - & 5,44 \\
\hline CV(\%) & - & - & & 28,16 & - & 4,13 & - & 11,47 & - & 18,94 & - & 27,62 & - & 20,80 \\
\hline
\end{tabular}

df, degrees of freedom; MS: mean square; Yield, seed yield in $\mathrm{kg} \mathrm{ha}^{-1}$, corrected to $13 \%$ moisture content; $100 \mathrm{M}, 100$-seed mass in g.; Plant architecture (PA) and tolerance to lodging (TL) (scores 1 to 9): 1, lines suitable for mechanized harvesting (short guides, high pods, closer branches, and without bedding); 9 , lines that are unable to be mechanically harvested (long guides, low pods, open branches, and lodged plants); SaP, seed appearance (scores 1 to 5): 1, commercial standard for carioca market class; 5 , lowest commercial quality or other market class; VS, Virus disease severity (scores 1 to 9 ): $1=$ no symptoms and $9=$ plot with $80-100 \%$ of plant diseases, or $60-100 \%$ of infected tissues (Melo, 2009); BGMV - bean golden mosaic virus, evaluated in the conventional controls (BRS Estilo and BRS FC402) and CPMMV - cowpea mild motle virus, evaluated in the elite progenies and in the transgenic control (BRS FC401 RMD); SA, selection accuracy. 


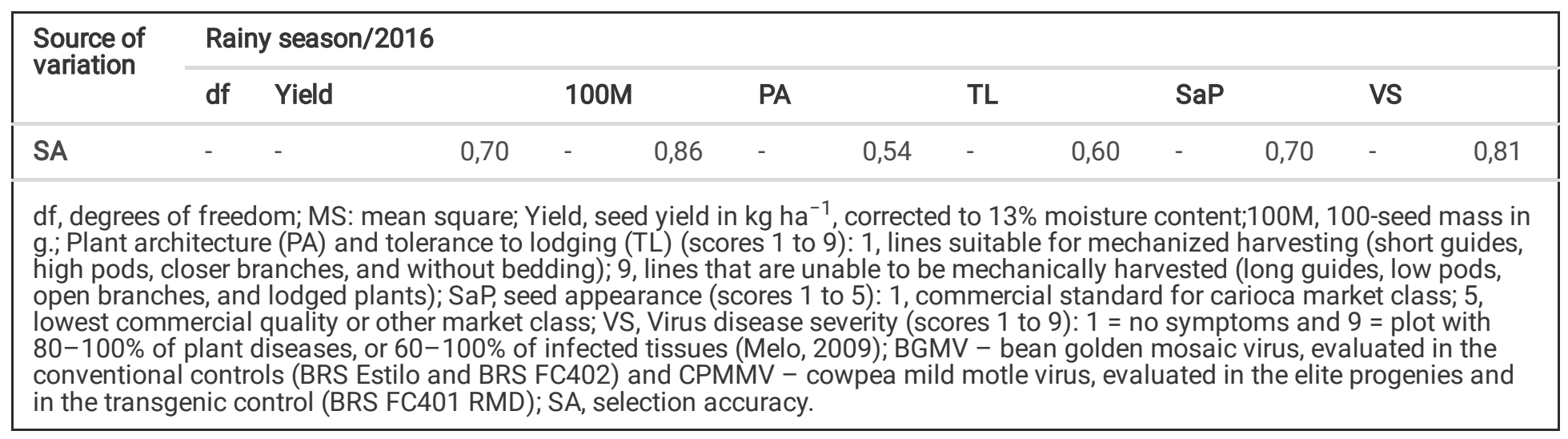

On the other hand, there were significant differences for most traits within treatments and within progenies, indicating that, in general, there is genetic variability between treatments. There was no variability for VS within controls (Table 4), meaning that the controls did not differ for their response to the virus diseases. The interaction between treatments and environment ( $T \times E)$ was significant $(P \leq 0.01)$ for most traits (Table 4). The interaction between progenies and environment $(P \times E)$ was significant for VS, which can be explained by the weather differences between the growing seasons (Pereira et al., 2019) probably leading to differential virus pressure (J. Faria et al., 2016; Souza et al., 2018). The variation shown for seed yield by the significant interaction between progeny (P) vs environments (E) (Table 4), represents a potential for continued selection for progenies 184-12.1, 356-5.1, 398-3.1, 417-22.1 and 422-39.1 in future agronomic trials, aiming at estimating stability and adaptability.

Common bean plants with upright architecture are preferred by farmers, as it allows mechanized harvesting in the field, reducing grain losses and improving grain quality (Faria et al., 2013; Barili et al., 2016). As a contribution to that demand, the development of modern cultivars by the Embrapa common bean breeding program has resulted in significant genetic progress for these two traits (PA and TL) over the years (Faria et al., 2013). In the present study, the majority of the elite progenies were statistically superior than the best controls (BRS Estilo and BRS FC402) for the traits PA and TL ( $95 \%$ and $92 \%$, respectively) (Table 1). The desirable patterns of PA and TL from both recurrent parents (Melo et al., 2010; Wendland et al., 2018) were successfully transferred to the 12 superior elite progenies selected for virus resistance. All the 12 selected progenies presented better PA scores than the best control (BRS Estilo, $\mathrm{PA}=5.3$ ), and 10 out of 12 presented better TL scores (Table 1).

Last, but no least, the elite progenies have also been evaluated for grain quality traits. The trait seed appearance (SaP) refers to the commercial value of the carioca market class standard for grains, which are the most consumed in Brazil, representing about $70 \%$ of the national market (Barili et al., 2016; J. Faria et al., 2016; Souza et al., 2018). In the present study, seven out of the 12 selected progenies were among the best scores for this trait, and did not differ from the control BRS Estilo (Table 1). The other five progenies did not differ from the average of the transgenic control, which also belongs to the carioca market class seeds (Table 1). In general, $56 \%$ of the elite progenies had SaP means statistically equal to the conventional control BRS Estilo (Table 1), indicating a good recovery of the desirable SaP scores. In the $\mathrm{BC}_{4} \mathrm{~F}_{4: 7}$ and $\mathrm{BC}_{3} \mathrm{~F}_{5: 8}$ (Figure 1) and in the $\mathrm{F}_{3: 7}$ and $\mathrm{F}_{4: 7}$ generations (Figure 2), the analysis of genetic similarity using molecular markers showed that the relative genetic similarities between recurrent parents and their progenies were $>97.8 \%$ (data not shown). Additionally, larger grains, evaluated by the trait 100-seed mass (100M), are preferred among consumers (Faria et al., 2013; Melo et al., 2017). The mean values of $100 \mathrm{M}$ ranged from $21.2 \mathrm{~g}$ to $24 \mathrm{~g}$ among the elite progenies (Table 1), being within the expected range for field evaluations without disease or insect management, as reported for other cultivars developed by Embrapa (L. C. Melo et al., 2017; Souza et al., 2016; Wendland et al., 2018). Twenty six percent of the elite progenies had statistically higher $100 \mathrm{M}$ averages than the best control (RMD) (Table 1) and among them, three out of the 12 selected virus resistant progenies.

The elite progenies selected for multiple virus resistance in the present study have potential for selection in future agronomic performance field evaluations, aiming to develop a common bean cultivar combining high yield to desirable agronomic and grain quality traits, such as the standard carioca market class seeds and suitability to mechanized harvesting. The RMD technology has proved its value as a technology transfer tool in the common bean breeding program, by applying biotechnology and traditional selection methods (Assefa et al., 2019; Meziadi et al., 2016, 2017; Patroti et al., 2019; Souza et al., 2018), which opens up new opportunities for strengthening a more sustainable bean production system in Brazil. 


\section{Declarations}

Acknowledgments

We sincerely thank José Francisco A. e Silva and Luana A. Rodrigues (Embrapa Arroz e Feijão) for important technical and logistic support.

Supplemental Material

Figure S1. RT-PCR analysis of mechanically inoculated common bean cultivars BRS Sublime, BRS FC401 RMD and the transgenic line CNFCT 19120 for detection of CPMMV. C+ is the positive control (previously inoculated and symptomatic common bean BRS FC401 RMD, resistant to BGMV), C- is the negative control (non-inoculated common bean plant cv. BRS FC401 RMD, resistant to BGMV) and water is the PCR control, without CDNA.

Statements \& Declarations

Funding

This work was supported by Brazilian Agricultural Research Corporation - Embrapa (Grant No. 20.18.04.008.00.00). T.L.P.O.S., R.S.S., H.S.P., L.C.M., A.L.F. and A.L.M.Z. are supported by the CNPq, the Brazilian Council for Scientific and Technological Development.

Competing Interests

The authors have no relevant financial or non-financial interests to disclose.

Author Contributions

T.L.P.O.S. and J.C.F. contributed to the study conception and design. Material preparation, data collection and analysis were performed by R.S.S, J.C.F., A.M.K., M.S.A., H.S.P., A.L.F., A.L.M.Z., P.V.P. The first draft of the manuscript was written by R.S.S and T.L.P.O.S. The final version was written by P.V.P. and T.L.P.O.S. All authors commented on previous versions of the manuscript. All authors read and approved the final manuscript.

Data Availability

Not applicable.

\section{References}

Alves-Freitas, D. M. T., Pinheiro-Lima, B., Faria, J. C., Lacorte, C., Ribeiro, S. G., \& Melo, F. L. (2019). Double-Stranded RNA HighThroughput Sequencing Reveals a New Cytorhabdovirus in a Bean Golden Mosaic Virus-Resistant Common Bean Transgenic Line. Viruses, 11(1). https://doi.org/10.3390/v11010090

Anderson, J. A., Gipmans, M., Hurst, S., Layton, R., Nehra, N., Pickett, J., Shah, D. M., Souza, T. L. P. O., \& Tripathi, L. (2016). Emerging Agricultural Biotechnologies for Sustainable Agriculture and Food Security. Journal of Agricultural and Food Chemistry, 64(2), 383393. https://doi.org/10.1021/acs.jafc.5b04543

Aragão, F. J. L., Nogueira, E. O. P. L., Tinoco, M. L. P., \& Faria, J. C. (2013). Molecular characterization of the first commercial transgenic common bean immune to the Bean golden mosaic virus. Journal of Biotechnology, 166(1), 42-50.

https://doi.org/10.1016/j.jbiotec.2013.04.009

Arf, O., Lemos, L., Sorrato, L., \& Ferrari, S. (2015). Aspectos gerais da cultura do feijão Phaseolus vulgaris L. (1 ${ }^{a}$ ed.). FEPAF.

Assefa, T., Assibi Mahama, A., Brown, A. V., Cannon, E. K. S., Rubyogo, J. C., Rao, I. M., Blair, M. W., \& Cannon, S. B. (2019). A review of breeding objectives, genomic resources, and marker-assisted methods in common bean (Phaseolus vulgaris L.). Molecular Breeding, 39(2), 20. https://doi.org/10.1007/s11032-018-0920-0

Page 15/22 
Barili, L. D., Vale, N. M., Moura, L. M., Paula, R. G., Silva, F. F., \& Carneiro, J. E. S. (2016). Genetic progress resulting from forty-three years of breeding of the carioca common bean in Brazil. Genetics and Molecular Research: GMR, 15(3).

https://doi.org/10.4238/gmr.15038523

Barros, M. de, \& Prudencio, S. H. (2016). Physical and chemical characteristics of common bean varieties. Semina: Ciências Agrárias, 37(2), 751-762. https://doi.org/10.5433/1679-0359.2016v37n2p751

Bonfım, K., Faria, J. C., Nogueira, E. O. P. L., Mendes, É. A., \& Aragão, F. J. L. (2007). RNAi-Mediated Resistance to Bean golden mosaic virus in Genetically Engineered Common Bean (Phaseolus vulgaris). Molecular Plant-Microbe Interactions, 20(6), 717-726. https://doi.org/10.1094/MPMI-20-6-0717

Brigide, P., Ataide, T. D. R., Canniatti-Brazaca, S. G., Baptista, A. S., Abdalla, A. L., Filho, V. F. N., Piedade, S. M. S., Bueno, N. B., \& Sant'ana, A. E. G. (2014). Iron bioavailability of common beans (Phaseolus vulgaris L.) intrinsically labeled with 59Fe. Journal of trace elements in medicine and biology, 28(3), 260-265. https://doi.org/10.1016/j.jtemb.2014.03.001

Chen, W., Hasegawa, D. K., Kaur, N., Kliot, A., Pinheiro, P. V., Luan, J., Stensmyr, M. C., Zheng, Y., Liu, W., Sun, H., Xu, Y., Luo, Y., Kruse, A., Yang, X., Kontsedalov, S., Lebedev, G., Fisher, T. W., Nelson, D. R., Hunter, W. B., ... Fei, Z. (2016). The draft genome of whitefly Bemisia tabaci MEAM1, a global crop pest, provides novel insights into virus transmission, host adaptation, and insecticide resistance. $B M C$ Biology, 14, 110. https://doi.org/10.1186/s12915-016-0321-y

Cheruku, D., Lal, S. K., Talukdar, A., \& Mandal, B. (2017). Inheritance and mapping of resistance against Cowpea mild mottle virus strain D1 in soybean. Plant Breeding, 136(2), 155-160. https://doi.org/10.1111/pbr.12455

Costa, A. S., Gaspar, J. O., \& Vega, J. (1983). Angular mosaic of the Phaseolus vulgaris variety Jalo, caused by a carlavirus transmitted by the white-fly Bemisia tabaci. Fitopatologia Brasileira, 8(2), 325-337.

Cruz, C. D. (2013). GENES: Software para análise de dados em estatística experimental e em genética quantitativa. Acta Scientiarum. Agronomy, 35(3), 271-276. https://doi.org/10.4025/actasciagron.v35i3.21251

Dinon, A. Z., Brod, F. C. A., Mello, C. S., Oliveira, E. M. M., Faria, J. C., \& Arisi, A. C. M. (2012). Primers and Probes Development for Specific PCR Detection of Genetically Modified Common Bean (Phaseolus vulgaris) Embrapa 5.1. Journal of Agricultural and Food Chemistry, 60(18), 4672-4677. https://doi.org/10.1021/jf3011257

Doyle, J., \& Doyle, J. (1990). Isolation of plant DNA from fresh tissue. Focus, 12, 13-15.

Embrapa Arroz e Feijão. (2019). Dados conjunturais do feijão (área, produção e rendimento) (Phaseolus vulgaris L.) no Brasil -1985 a 2016. http://www.cnpaf.embrapa.br/socioeconomia/index.htm

FAOSTAT. (2020). Food and Agriculture Organization of the United Nations-Statistics Division. www.faostat.org

Faria, J., Aragao, F. J. L., Souza, T. L. P. O., Quintela, E. D., Kitajima, E. W., \& Ribeiro, S. G. (2016). Golden mosaic of common beans in Brazil: Management with a transgenic approach. APS Features, 10. https://doi.org/10.1094

Faria, J. C., Valdisser, P. A. M. R., Nogueira, E. O. P. L., \& Aragão, F. J. L. (2014). RNAi-based Bean golden mosaic virus-resistant common bean (Embrapa 5.1) shows simple inheritance for both transgene and disease resistance. Plant Breeding, $133(5), 649-653$. https://doi.org/10.1111/pbr.12189

Faria, L. C., Melo, P. G. S., Pereira, H. S., Peloso, M. J. D., Brás, A. J. B. P., Moreira, J. A. A., de Carvalho, H. W. L., \& Melo, L. C. (2013). Genetic progress during 22 years of improvement of carioca-type common bean in Brazil. Field Crops Research, $142,68-74$. https://doi.org/10.1016/j.fcr.2012.11.016

Faria, L. C., Melo, P. G. S., Pereira, H. S., Wendland, A., Borges, S. F., Filho, I. A. P., Diaz, J. L. C., Calgaro, M., \& Melo, L. C. (2014). Genetic progress during 22 years of black bean improvement. Euphytica, 199(3), 261-272. https://doi.org/10.1007/s10681-014-1135-z

Gil, J., Solarte, D., Lobaton, J. D., Mayor, V., Barrera, S., Jara, C., Beebe, S., \& Raatz, B. (2019). Fine-mapping of angular leaf spot resistance gene Phg-2 in common bean and development of molecular breeding tools. Theoretical and Applied Genetics, 132(7),

Page 16/22 
Iwaki, M., Thongmeearkom, P., Prommin, M., Honda, Y., \& Hibi, T. (1982). Whitefly transmission and some properties of cowpea mild mottle virus on soybean in Thailand. Plant Disease, 66(5), 365-368.

Jeyanandarajah, P., \& Brunt, A. A. (1993). The Natural Occurrence, Transmission, Properties and Possible Affinities of Cowpea Mild Mottle Virus. Journal of Phytopathology, 137(2), 148-156. https://doi.org/10.1111/j.1439-0434.1993.tb01334.x

Lobaton, J. D., Miller, T., Gil, J., Ariza, D., Hoz, J. F. de la, Soler, A., Beebe, S., Duitama, J., Gepts, P., \& Raatz, B. (2018). Resequencing of Common Bean Identifies Regions of Inter-Gene Pool Introgression and Provides Comprehensive Resources for Molecular Breeding. The Plant Genome, 11(2), 170068. https://doi.org/10.3835/plantgenome2017.08.0068

Martins, S. M., Melo, P. G. S., Faria, L. C., Souza, T. L. P. O., Melo, L. C., \& Pereira, H. S. (2016). Genetic parameters and breeding strategies for high levels of iron and zinc in Phaseolus vulgaris L. Genetics and Molecular Research: GMR, 15(2). https://doi.org/10.4238/gmr.15028011

Marubayashi, J. M., Yuki, V. A., \& Wutke, E. B. (2010). Transmission of the Cowpea mild mottle virus by whitefly Bemisia tabaci biotype B for plants of beans and soy. Summa Phytopathologica, 36(2), 158-160. https://doi.org/10.1590/S010054052010000200009

Melo, L. (2009). Procedimentos para Condução de Experimentos de Valor de Cultivo e Uso em Feijoeiro-comum. (Documentos / Embrapa Arroz e Feijão, 239). Santo Antônio de Goiás - GO: Embrapa Arroz e Feijão.

Melo, L. C., Peloso, M. J. D., Pereira, H. S., Faria, L. C. de, Costa, J. G. C. da, Díaz, J. L. C., Rava, C. A., Wendland, A., \& Abreu, Â. de F. B. (2010). BRS Estilo: Common bean cultivar with Carioca grain, upright growth and high yield potential. Crop Breeding and Applied Biotechnology, 10(4), 377-379. https://doi.org/10.1590/S1984-70332010000400015

Melo, L. C., Pereira, H. S., Faria, L. C. de, Souza, T. L. P. O. de, Wendland, A., Díaz, J. L. C., Carvalho, H. W. L. de, Melo, C. L. P. de, Costa, A. F. da, Magaldi, M. C. de S., \& Costa, J. G. C. da. (2017). BRS FC402: High-yielding common bean cultivar with carioca grain, resistance to anthracnose and fusarium wilt. Crop Breeding and Applied Biotechnology, 17(1), 67-71. https://doi.org/10.1590/198470332017v17n1c11

Melotto, M., Afanador, L., \& Kelly, J. D. (1996). Development of a SCAR marker linked to the I gene in common bean. Genome, 39(6), 1216-1219. https://doi.org/10.1139/g96-155

Meziadi, C., Blanchet, S., Geffroy, V., \& Pflieger, S. (2017). Genetic resistance against viruses in Phaseolus vulgaris L.: State of the art and future prospects. Plant Science: An International Journal of Experimental Plant Biology, 265, 39-50.

https://doi.org/10.1016/j.plantsci.2017.08.009

Meziadi, C., Richard, M. M. S., Derquennes, A., Thareau, V., Blanchet, S., Gratias, A., Pflieger, S., \& Geffroy, V. (2016). Development of molecular markers linked to disease resistance genes in common bean based on whole genome sequence. Plant Science, 242, 351357. https://doi.org/10.1016/j.plantsci.2015.09.006

Miklas, P. N., Kelly, J. D., Beebe, S. E., \& Blair, M. W. (2006). Common bean breeding for resistance against biotic and abiotic stresses: From classical to MAS breeding. Euphytica, 147(1), 105-131. https://doi.org/10.1007/s10681-006-4600-5

Morais, S. R. P. de, Vieira, A. F., Almeida, L. C. da S., Rodrigues, L. A., Melo, P. G. S., Faria, L. C. de, Melo, L. C., Pereira, H. S., Souza, T. L. P. O. de, Morais, S. R. P. de, Vieira, A. F., Almeida, L. C. da S., Rodrigues, L. A., Melo, P. G. S., Faria, L. C. de, Melo, L. C., Pereira, H. S., \& Souza, T. L. P. O. de. (2016). Application of microsatellite markers to confirm controlled crosses and assess genetic identity in common bean. Crop Breeding and Applied Biotechnology, 16(3), 234-239. https://doi.org/10.1590/1984-70332016v16n3n35

Mukiibi, D. R., Alicai, T., Kawuki, R., Okao-Okuja, G., Tairo, F., Sseruwagi, P., Ndunguru, J., \& Ateka, E. M. (2019). Resistance of advanced cassava breeding clones to infection by major viruses in Uganda. Crop Protection, 115, 104-112.

https://doi.org/10.1016/j.cropro.2018.09.015

Page $17 / 22$ 
Patroti, P., Vishalakshi, B., Umakanth, B., Suresh, J., Senguttuvel, P., \& Madhav, M. S. (2019). Marker-assisted pyramiding of major blast resistance genes in Swarna-Sub1, an elite rice variety (Oryza sativa L.). Euphytica, 215(11), 179.

https://doi.org/10.1007/s10681-019-2487-1

Pereira, D. G., Faria, L. C., Souza, T. L. P. O., Melo, L. C., \& Pereira, H. S. (2019). Selection of parents and segregating populations of black bean resistant to fusarium wilt with high yield and seed weight. GMR / Genetics and Molecular Research / The Original by FUNPEC-RP, 18. https://www.geneticsmr.com/articles/selection-parents-and-segregating-populations-black-bean-resistant-fusariumwilt-high-yield

Ramalho, M., Ferreira, D., \& Oliveira, A. (2012). Experimentação em Genética e Melhoramento de Plantas. (3. ed.). UFLA.

Resende, M. D. V., \& Duarte, J. B. (2007). Precisão e controle de qualidade em experimentos de avaliação de cultivares. Pesqui. Agropecu. Trop, 37(3), 182-194.

Scott, A. J., \& Knott, M. (1974). A Cluster Analysis Method for Grouping Means in the Analysis of Variance. Biometrics, 30(3), 507512. JSTOR. https://doi.org/10.2307/2529204

Souza, T. L. P. O., Faria, J. C., Aragao, F. J. L., Del Peloso, M. J., Faria, L. C., Aguiar, M. S., Wendland, A., Quintela, E. D., Diaz, J. L. C., Magaldi, M., Souza, N. P., Costa, A. G., Trindade, N., Marangon, M. A., Melo, C. L. P., Hungria, M., Pereira Filho, I. A., Wruck, F. J., Almeida, V. M., ... Melo, L. C. (2016). BRS FC401 RMD: cultivar de feijão carioca geneticamente modificada com resistência ao mosaico-dourado.

Souza, T. L. P. O., Faria, J. C., Aragão, F. J. L., Peloso, M. J. D., Faria, L. C., Wendland, A., Aguiar, M. S., Quintela, E. D., Melo, C. L. P., Hungria, M., Vianello, R. P., Pereira, H. S., \& Melo, L. C. (2018). Agronomic Performance and Yield Stability of the RNA InterferenceBased Bean golden mosaic virus-Resistant Common Bean. Crop Science, 58(2), 579-591.

https://doi.org/10.2135/cropsci2017.06.0355

Thouvenel, J. C., Monsarrat, A., \& Fauquet, C. (1982). Isolation of cowpea mild mottle virus from diseased soybeans in the Ivory Coast. Plant Disease, 66(4), 336-337.

Vlasova, A., Capella-Gutiérrez, S., Rendón-Anaya, M., Hernández-Oñate, M., Minoche, A. E., Erb, I., Câmara, F., Prieto-Barja, P., Corvelo, A., Sanseverino, W., Westergaard, G., Dohm, J. C., Pappas, G. J., Saburido-Alvarez, S., Kedra, D., Gonzalez, I., Cozzuto, L., GómezGarrido, J., Aguilar-Morón, M. A., ... Guigó, R. (2016). Genome and transcriptome analysis of the Mesoamerican common bean and the role of gene duplications in establishing tissue and temporal specialization of genes. Genome Biology, $17(1), 32$.

https://doi.org/10.1186/s13059-016-0883-6

Wendland, A., Pereira, H. S., Faria, L. C. de, Souza, T. L. P. O., Peloso, M. J. D., Costa, J. G. C. da, Díaz, J. L. C., Magaldi, M. C. de S., Almeida, V. M. de, Carvalho, H. W. L. de, Melo, C. L. P. de, Costa, A. F. da, Abreu, Â. de F. B., Melo, L. C., Wendland, A., Pereira, H. S., Faria, L. C. de, Souza, T. L. P. O., Peloso, M. J. D., ... Melo, L. C. (2018). BRS Sublime-Common bean cultivar with carioca grain, resistance to angular leaf spot and high nutritional quality. Crop Breeding and Applied Biotechnology, 18(4), 440-445.

https://doi.org/10.1590/1984-70332018v18n4c65

Yi, J., Njoroge, D. M., Sila, D. N., Kinyanjui, P. K., Christiaens, S., Bi, J., \& Hendrickx, M. E. (2016). Detailed analysis of seed coat and cotyledon reveals molecular understanding of the hard-to-cook defect of common beans (Phaseolus vulgaris L.). Food Chemistry, 210, 481-490. https://doi.org/10.1016/j.foodchem.2016.05.018

\section{Figures}




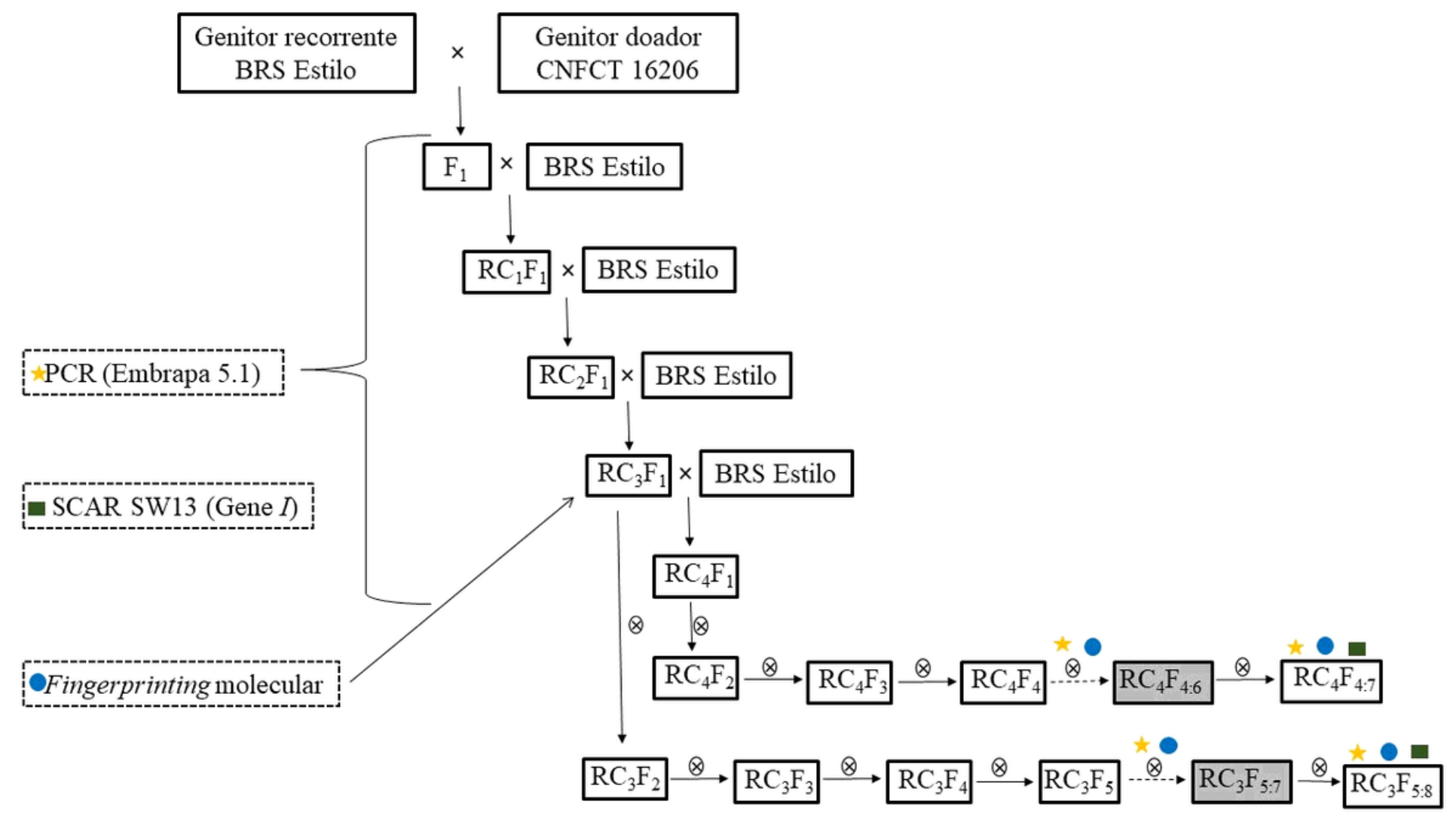

Figure 1

Diagram representing the breeding strategy used to develop genetically modified progenies of common bean resistant to viruses, by crossing the cultivar BRS Estilo and the transgenic line CNFCT 16206, carrier of the event Embrapa 5.1. 


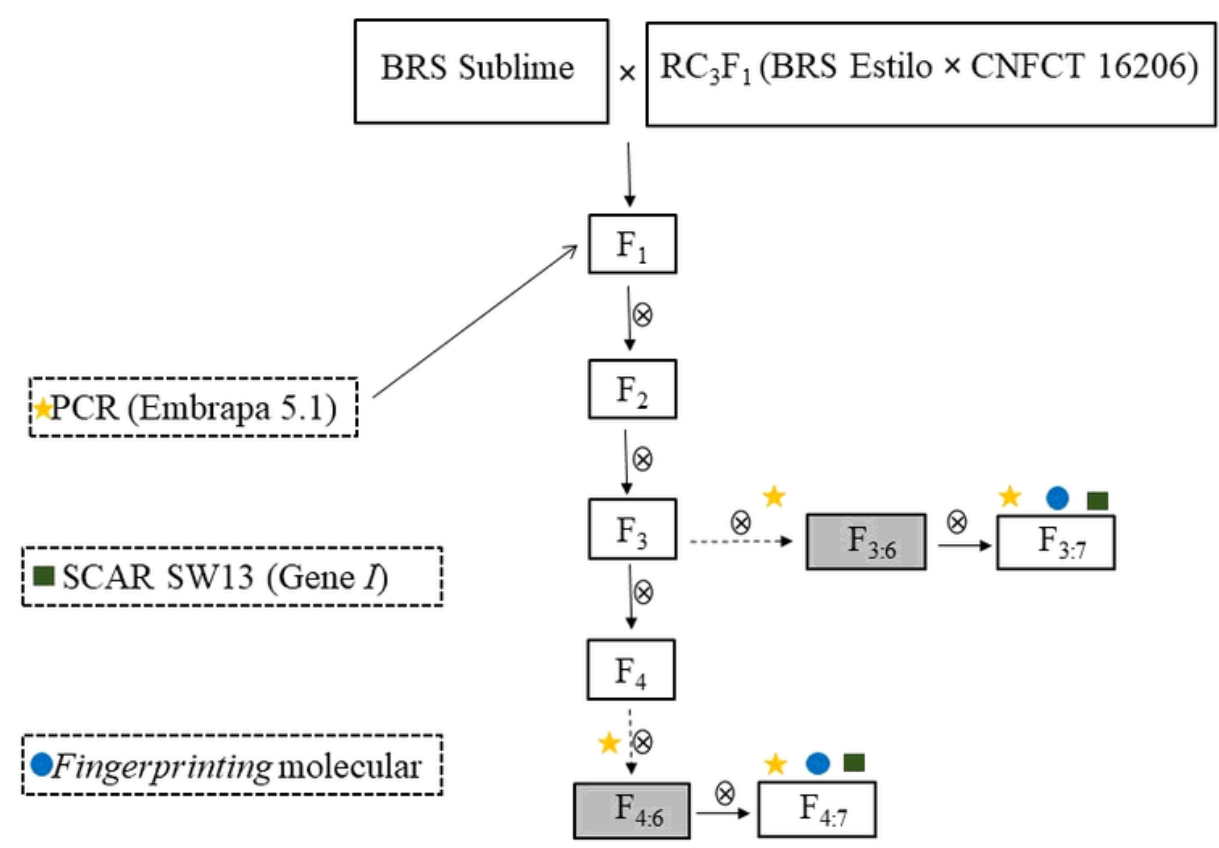

\section{Figure 2}

Representative diagram of the breeding strategy used in the development of genetically modified common bean progenies for resistance to viruses by crossing the BRS Sublime cultivar with $\mathrm{BC}_{3} \mathrm{~F}_{1}$ plants from the BRS Estilo $\times$ CNFCT 16206 crossing (Embrapa 5.1). 
A

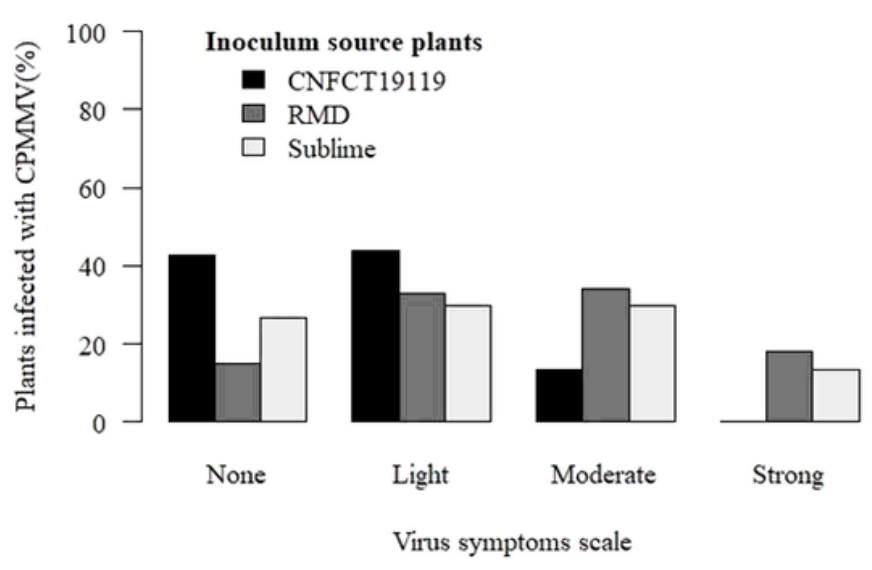

B

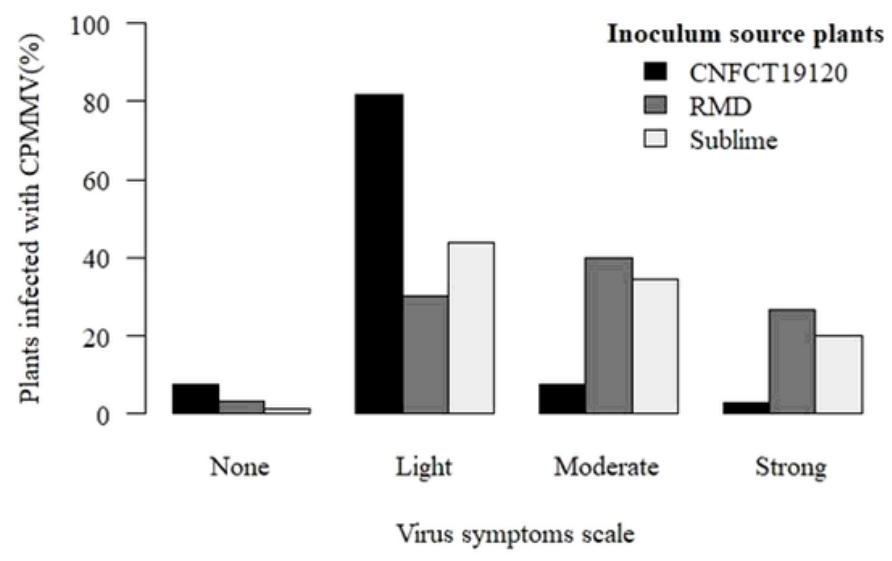

Figure 3

Percentage of CPMMV infected plants showing different levels of symptoms varying the inoculum source and test plants: A) CNFCT 19119, BRS Sublime and BRS FC401 RMD and B) CNFCT 19120, BRS Sublime and BRS FC401 RMD. Test plants, inoculated by whiteflies, were visually evaluated using a 1-4 scoring scale of CPMMV symptoms, where 1=none, $2=$ light, $3=$ moderate and $4=$ strong. BRS Sublime and BRS FC401 RMD were used as controls, considering that BRS Sublime is resistant to CPMMV, while BRS FC401 RMD is susceptible to this virus. (Chi-square $p<0.05$ ). 
A

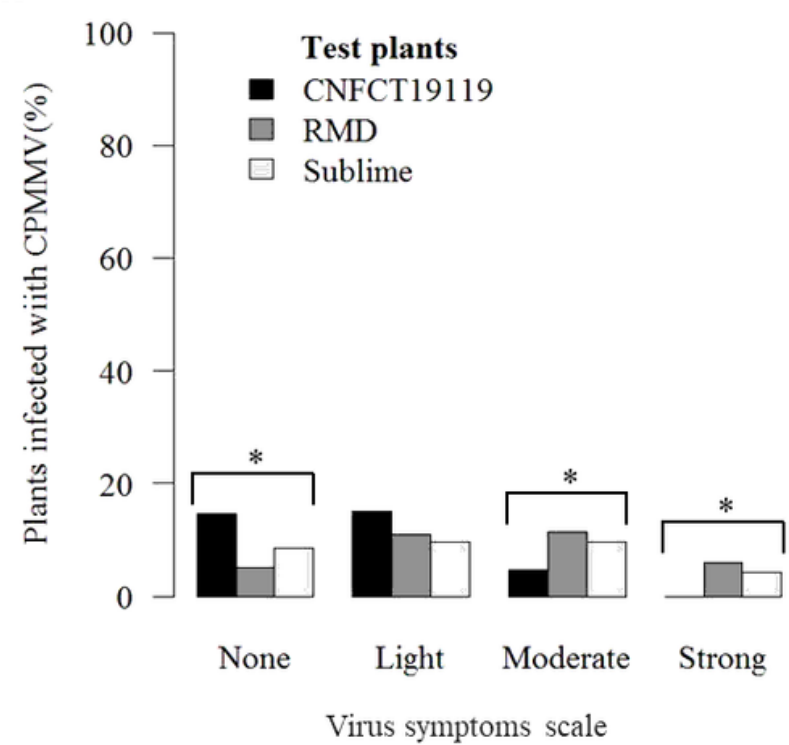

B

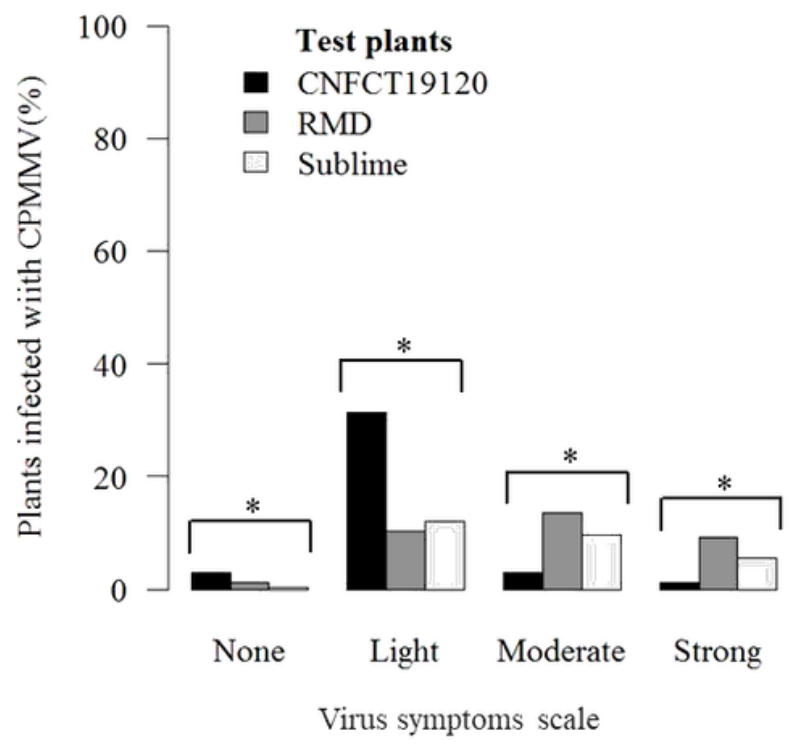

Figure 4

Percentage of CPMMV infected plants showing different levels of symptoms, varying the inoculum source A) CNFCT 19119 and B) CNFCT 19120. Test plants, inoculated by whiteflies, were visually evaluated using a 1-4 scoring scale of CPMMV symptoms, where 1=none, 2=light, 3=moderate and 4=strong. BRS Sublime and BRS FC401 RMD were used as controls, considering that BRS Sublime is resistant to CPMMV, while BRS FC401 RMD is susceptible to this virus. Proportions of plants showing different scores for virus symptoms were analyzed by the Pearson's Chi-square test $(p<0.05)$ and the proportion of plants within each grade of the scoring scale were compared using the Equality of proportions hypothesis test $(p<0.05)$. 